\title{
Federal and regional standards for highways maintenance and repair costs
}

\author{
Dmitry Filippov* and Elena Grigoryeva \\ North Eastern Federal University, 58, Belinsky street, Yakutsk, 677000, Russia
}

\begin{abstract}
The current conditions of Russian territories road infrastructure, regional budgetary funding, differences in economic potential and the economy structure of the constituent entities of the Russian Federation determine the relevance of the development and improvement of the regional regulatory base. This is important in the field of tariff policy, one of the elements of which is the approval of basic standards and rules for calculating the amount of budgetary funds for capital repairs, repairs and maintenance of regional road network. This article is devoted to the study of the regional practice that has developed in the Russian Federation for the establishment of standard costs for capital repairs, repairs and maintenance of regional and intermunicipal roads in comparison with federal ones. The work consists of two logically related structural elements: an overview and an analytical part. The review revealed the differentiation of the size of budgetary allocations in the context of subjects and federal districts. In the analytical part, an attempt is made to determine the closeness between federal and regional standards and, as a result, to identify the range of regions that practice linking regional standards to federal ones.
\end{abstract}

\section{Introduction}

According to the results of control measures of the Accounts Chamber of the Russian Federation [1] at the beginning of $2020,85 \%$ of the federal road network meets the regulatory requirements for the quality of content. With regard to the regional road network, this indicator improved compared to 2017 by only $1.1 \%$ and amounted to only $44.2 \%$. If the volume of budget allocations for the maintenance of the federal road network in 2019 amounted to 2,242 thousand roubles / $\mathrm{km}$, then 288 thousand roubles / $\mathrm{km}$, or 7.7 times less, were allocated for the regional road network.

At present, a "high" level of maintenance of the federal road network has been established; the values of the regional road network must be brought to the same level, taking into account their transport and operational status. As a result, it was proposed to revise and justify the change in the standards for the maintenance and maintenance costs of the regional road network in the constituent entities of the Russian Federation.

This paper presents the results of a study of the regional practice that has developed in the Russian Federation to establish the standard costs for capital repairs, repairs and maintenance of regional and intermunicipal roads in comparison with federal ones.

\section{Research methods}

The work uses statistical and comparative methods for analysing quantitative data. Thus, by calculating the standard statistical indicators of the standard deviation and the coefficient of variation, the numerical values of the scatter were calculated. Then we compared with the standard values of the deviations in accordance with the methodology proposed in Federal Law No. 44.

When studying the degree of influence of external and internal factors affecting the amount of cash costs for the maintenance, repair and capital repair of regional and intermunicipal roads, the authors relied on a number of scientific works on the research problem. Issues of regional de-differentiation of the cost of work (services) and goods, including road construction, are considered in the following works [2-7]. The methodological basis of the study was based on scientific works [8-10], justifying the influence of the factors of cost increasing in capital repairs of the regional road network, taking into account transport accessibility and remoteness from the local centres of the transport system. There are various techniques and methodological approaches to calculating the standards of monetary costs for the maintenance of highways [11-13], including taking into account the turnaround time [14], the cost of maintaining special road equipment (fuel, spare parts, repairs) [15] and others [16].

Due to the presence of variability in the implementation of repair and maintenance work, it is impossible to achieve strict adherence to real costs. In order to achieve the quality indicators of the work carried out, it is necessary to establish their standard values. In this regard, one of the most important tasks of quality management is to reduce the variation of processes and their results, the solution of which is impossible without the use of various statistical methods. The use of statistical methods makes it possible to

Corresponding author: fil_dv@mail.ru 
collect, process and analyze data in order to turn them into objective and reliable information necessary for making informed decisions.

\section{Analysis}

In accordance with adopted hypothesis, the target benchmark of the standards for financing federal highways was defined as a reference. However, "blind copying" of federal norms and standards in the corresponding documents of the regional level is unfounded. In this connection, regulatory documents, similar rules and practices for calculating the monetary costs of the Russian Federation regions were collected, studied and analyzed. Namely, Belgorod Region, Komi Republic, Rostov Region, Chechen Republic, Bashkortostan Republic, Khanty-Mansi Autonomous Region, the Novosibirsk Region are presented in Table 1 .

Table 1. Analysis of the regional to federal standards ratio for maintenance, repair and capital repair of regional and intermunicipal roads in prices of 2019.

\begin{tabular}{|c|c|c|c|c|}
\hline \multirow[t]{2}{*}{ No. } & \multirow{2}{*}{$\begin{array}{c}\text { Subject of the } \\
\text { Russian Federation }\end{array}$} & \multicolumn{3}{|c|}{$\begin{array}{l}\text { Ratio of regional to } \\
\text { federal standard } \\
\text { (coefficient } 1,00)\end{array}$} \\
\hline & & maintenance & repair & $\begin{array}{l}\text { capital } \\
\text { repair }\end{array}$ \\
\hline 1 & $\begin{array}{c}\text { Belgorod Region } \\
\text { (Central Federal } \\
\text { District) }\end{array}$ & $0.59(1.02 *)$ & $\begin{array}{c}0.46 \\
(1.07)\end{array}$ & $\begin{array}{c}0.58 \\
(1.07)\end{array}$ \\
\hline 2 & $\begin{array}{l}\text { Komi Republic } \\
\text { (North Western } \\
\text { Federal District) } \\
\end{array}$ & $0.20(1.35)$ & $\begin{array}{l}1.76 \\
(1.33)\end{array}$ & $\begin{array}{c}1.85 \\
(1.37)\end{array}$ \\
\hline 3 & $\begin{array}{l}\text { Rostov Region } \\
\text { (Southern } \\
\text { Federal District) }\end{array}$ & $0.80(0.83)$ & $\begin{array}{c}0.96 \\
(0.82)\end{array}$ & $\begin{array}{c}1.01 \\
(0.86)\end{array}$ \\
\hline 4 & $\begin{array}{c}\text { Chechen } \\
\text { Republic (North } \\
\text { Caucasian } \\
\text { Federal District) }\end{array}$ & $0.71(0.76)$ & $\begin{array}{c}0.93 \\
(0.89)\end{array}$ & $\begin{array}{c}0.96 \\
(0.92)\end{array}$ \\
\hline 5 & $\begin{array}{l}\text { Bashkortostan } \\
\text { Republic (Volga } \\
\text { Federal District) }\end{array}$ & $0.40(1.00)$ & $\begin{array}{c}0.88 \\
(0.68)\end{array}$ & $\begin{array}{c}0.86 \\
(0.66)\end{array}$ \\
\hline 6 & $\begin{array}{c}\text { Khanty-Mansi } \\
\text { Autonomous } \\
\text { Region (Ural } \\
\text { Federal District) }\end{array}$ & $1.01(0.98)$ & $\begin{array}{l}1.06 \\
(0.97)\end{array}$ & $\begin{array}{l}1.06 \\
(1.03)\end{array}$ \\
\hline 7 & $\begin{array}{c}\text { Novosibirsk } \\
\text { Region (Siberian } \\
\text { Federal District) }\end{array}$ & $1.04(1.06)$ & $\begin{array}{c}0.99 \\
(0.93)\end{array}$ & $\begin{array}{l}1.03 \\
(0.96)\end{array}$ \\
\hline 8 & $\begin{array}{c}\text { Republic of } \\
\text { Sakha (Yakutia) } \\
\text { (Far Eastern } \\
\text { Federal District) }\end{array}$ & $0.58(1.58)$ & $\begin{array}{c}1.21 \\
(1.73)\end{array}$ & $\begin{array}{c}0.90 \\
(1.73)\end{array}$ \\
\hline
\end{tabular}

Explanation: * in brackets there are the values of the ratio of the federal district to the whole Russian Federation standard
The sample of the listed regions was made according to the principle of considering one of the Russian Federation region from each federal district. For each region of the Federation, in strict accordance with the established local rules, the values of regional and federal standards were calculated for the corresponding federal district to which the studied region belongs. Estimated standards for constituent entities and federal districts are reduced to 2019 prices based on the approved consumer price deflator indices to the standards for the maintenance and deflator indices of investments in fixed assets to the repair and capital repair, in accordance with current rules are presented in Table 2.

Table 2. Calculation of standard and deviation. Capital repair $(\mathrm{i}=1)$.

\begin{tabular}{|c|c|c|c|c|}
\hline \multirow[b]{2}{*}{ No. } & \multirow[b]{2}{*}{$\begin{array}{c}\text { Subjects of the } \\
\text { Russian Federation }\end{array}$} & \multicolumn{2}{|c|}{ Standard } & \multirow{2}{*}{$\begin{array}{c}\begin{array}{c}\text { Deviat } \\
\text { ion }\end{array} \\
X_{i}-X\end{array}$} \\
\hline & & $\begin{array}{c}\text { Regio } \\
\text { nal } \\
\left(X_{\mathrm{i}}\right)\end{array}$ & $\begin{array}{l}\text { Federal } \\
\text { District } \\
\quad(\mathrm{X})\end{array}$ & \\
\hline 1 & $\begin{array}{c}\text { Belgorod Region } \\
\text { (Central Federal } \\
\text { District) } \\
\end{array}$ & 7549 & 13991 & -6442 \\
\hline 2 & $\begin{array}{l}\text { Komi Republic } \\
\text { (North Western } \\
\text { Federal District) }\end{array}$ & 24250 & 17912 & 6338 \\
\hline 3 & $\begin{array}{c}\text { Rostov Region } \\
\text { (Southern Federal } \\
\text { District) }\end{array}$ & 13230 & 11285 & 1945 \\
\hline 4 & $\begin{array}{c}\text { Chechen Republic } \\
\text { (North Caucasian } \\
\text { Federal District) }\end{array}$ & 12591 & 12063 & 528 \\
\hline 5 & $\begin{array}{l}\text { Bashkortostan } \\
\text { Republic (Volga } \\
\text { Federal District) }\end{array}$ & 11302 & 8695 & 2607 \\
\hline 6 & $\begin{array}{l}\text { Khanty-Mansi } \\
\text { Autonomous } \\
\text { Region (Ural } \\
\text { Federal District) }\end{array}$ & 13866 & 13434 & 432 \\
\hline 7 & $\begin{array}{c}\text { Novosibirsk } \\
\text { Region (Siberian } \\
\text { Federal District) } \\
\end{array}$ & 13441 & 12510 & 931 \\
\hline 8 & $\begin{array}{c}\text { Republic of Sakha } \\
\text { (Yakutia) (Far } \\
\text { Eastern Federal } \\
\text { District) }\end{array}$ & 11805 & 22658 & -10853 \\
\hline
\end{tabular}

The results obtained show that within the federal districts there is a significant differentiation in the cost of standards. Especially this aspect is typical of the northern regions, such as Komi Republic, Republic of Sakha (Yakutia).

\section{Assessment of the tightness of the relationship between regional and federal standards}


The coefficient of variation refers to a measure of the relative spread of prices offered. It shows how much the average price range is from the average price value. According to the Federal Law (FL) No. 44 the coefficient of variation is an indicator of the spread for the selected price proposals of the tender, which is used when using the method of comparable market prices. This indicator can take the following values:

- less than $10 \%$ - in this case, the difference in prices is considered insignificant;

- from $10 \%$ to $20 \%$ - the spread is considered average;

- from $20 \%$ to $33 \%$ - the difference is recognized as significant, but acceptable;

- over $33 \%$ - the data is heterogeneous, when calculating the contract price it is not allowed to use data with a coefficient of variation over $33 \%$.

According to the Federal Law No. 44 the permissible coefficient of variation is up to $33 \%$. Calculations of the magnitude of the variance and the coefficient of variation in comparing the standards between regional and federal values for the overhaul of highways are presented in Table 3.

Table 3. Calculation of variance and coefficient of variation. Capital repair $(i=1)$.

\begin{tabular}{|c|c|c|c|c|c|}
\hline \multirow[b]{2}{*}{ No. } & \multirow{2}{*}{$\begin{array}{l}\text { Subjects of } \\
\text { the Russian } \\
\text { Federation }\end{array}$} & \multirow{2}{*}{$\begin{array}{c}\begin{array}{c}\text { Varia } \\
\text { nce }\end{array} \\
\sigma\end{array}$} & \multicolumn{2}{|c|}{$\begin{array}{l}\text { Coefficient of } \\
\text { variation }\end{array}$} & \multirow{2}{*}{$\begin{array}{c}\text { Interpreta } \\
\text { tion of CV } \\
\text { by FL No. } \\
44\end{array}$} \\
\hline & & & $\begin{array}{l}\mathrm{CV} \text {, } \\
\text { units }\end{array}$ & $\mathrm{CV}, \%$ & \\
\hline 1 & $\begin{array}{l}\text { Belgorod } \\
\text { Region } \\
\text { (Central } \\
\text { Federal } \\
\text { District) }\end{array}$ & 6442 & 0.85 & $85.3 \%$ & $\begin{array}{l}\text { The } \\
\text { difference } \\
\text { is not valid }\end{array}$ \\
\hline 2 & $\begin{array}{c}\text { Komi } \\
\text { Republic } \\
\text { (North } \\
\text { Western } \\
\text { Federal } \\
\text { District) } \\
\end{array}$ & 6338 & 0.26 & $26.1 \%$ & $\begin{array}{c}\text { The } \\
\text { difference } \\
\text { is } \\
\text { significant, } \\
\text { but } \\
\text { acceptable }\end{array}$ \\
\hline 3 & $\begin{array}{c}\text { Rostov } \\
\text { Region } \\
\text { (Souther } \\
\text { n Federal } \\
\text { District) }\end{array}$ & 1945 & 0.15 & $14.7 \%$ & $\begin{array}{c}\text { Average } \\
\text { difference }\end{array}$ \\
\hline 4 & $\begin{array}{c}\text { Chechen } \\
\text { Republic } \\
\text { (North } \\
\text { Caucasia } \\
\text { n Federal } \\
\text { District) }\end{array}$ & 528 & 0.04 & $4.2 \%$ & $\begin{array}{c}\text { The } \\
\text { difference } \\
\text { is } \\
\text { insignifica } \\
\text { nt }\end{array}$ \\
\hline 5 & $\begin{array}{c}\text { Bashkort } \\
\text { ostan } \\
\text { Republic } \\
\text { (Volga } \\
\text { Federal }\end{array}$ & 2607 & 0.23 & $23.1 \%$ & $\begin{array}{c}\text { The } \\
\text { difference } \\
\text { is } \\
\text { significant, } \\
\text { but } \\
\text { acceptable }\end{array}$ \\
\hline
\end{tabular}

\begin{tabular}{|c|c|l|l|l|l|}
\hline & District) & & & & \\
\hline $\mathbf{6}$ & $\begin{array}{c}\text { Khanty- } \\
\text { Mansi } \\
\text { Autonom } \\
\text { Ous } \\
\text { Region } \\
\text { (Ural } \\
\text { Federal } \\
\text { District) }\end{array}$ & 432 & 0.03 & $3.1 \%$ & $\begin{array}{c}\text { The } \\
\text { difference } \\
\text { is } \\
\text { insignifica } \\
\text { nt }\end{array}$ \\
\hline $\mathbf{7}$ & $\begin{array}{c}\text { Novosibir } \\
\text { Sk Region } \\
\text { (Siberian } \\
\text { Federal } \\
\text { District) }\end{array}$ & 931 & 0.07 & $6.9 \%$ & $\begin{array}{c}\text { The } \\
\text { is } \\
\text { insignifica } \\
\text { nt }\end{array}$ \\
\hline & $\begin{array}{c}\text { Republic } \\
\text { of Sakha } \\
\text { (Yakutia) } \\
\text { (Far } \\
\text { Eastern } \\
\text { Federal } \\
\text { District) }\end{array}$ & 10853 & 0.92 & $91.9 \%$ & $\begin{array}{c}\text { The } \\
\text { difference } \\
\text { is not valid }\end{array}$ \\
\hline
\end{tabular}

As a result, high values of the coefficient of variation were obtained in two regions - Republic of Sakha (Yakutia) and Belgorod Region. Determined heterogeneity of values, means that the standards used in budget allocations calculating for roads capital repair in these regions do not correspond to the federal level and require a reasonable revaluation. The results of determining of the regional and federal standards dispersion for the roads repair are presented in Table 4 .

Table 4. Calculation of variance and coefficient of variation. Repair (i = 1).

\begin{tabular}{|c|c|c|c|c|c|}
\hline \multirow[b]{2}{*}{ No. } & \multirow{2}{*}{$\begin{array}{l}\text { Subjects of } \\
\text { the Russian } \\
\text { Federation }\end{array}$} & \multirow{2}{*}{$\begin{array}{c}\text { Varia } \\
\text { nce }\end{array}$} & \multicolumn{2}{|c|}{$\begin{array}{l}\text { Coefficient of } \\
\text { variation }\end{array}$} & \multirow{2}{*}{$\begin{array}{c}\text { Interpreta } \\
\text { tion of CV } \\
\text { by FL No. } \\
44\end{array}$} \\
\hline & & & $\begin{array}{l}\mathrm{CV}, \\
\text { units }\end{array}$ & $\begin{array}{l}\mathrm{CV}, \\
\%\end{array}$ & \\
\hline 1 & $\begin{array}{c}\text { Belgorod } \\
\text { Region } \\
\text { (Central } \\
\text { Federal } \\
\text { District) }\end{array}$ & 3134 & 1.31 & $\begin{array}{c}131.3 \\
\%\end{array}$ & $\begin{array}{l}\text { The } \\
\text { difference } \\
\text { is not valid }\end{array}$ \\
\hline 2 & $\begin{array}{c}\text { Komi } \\
\text { Republic } \\
\text { (North } \\
\text { Western } \\
\text { Federal } \\
\text { District) }\end{array}$ & 2203 & 0.24 & $24.2 \%$ & $\begin{array}{c}\text { The } \\
\text { difference } \\
\text { is } \\
\text { significant. } \\
\text { but } \\
\text { acceptable }\end{array}$ \\
\hline 3 & $\begin{array}{c}\text { Rostov } \\
\text { Region } \\
\text { (Souther } \\
\text { n Federal } \\
\text { District) }\end{array}$ & 730 & 0.15 & $14.7 \%$ & $\begin{array}{c}\text { Average } \\
\text { difference }\end{array}$ \\
\hline 4 & $\begin{array}{l}\text { Chechen } \\
\text { Republic }\end{array}$ & 202 & 0.04 & $4.2 \%$ & $\begin{array}{c}\text { The } \\
\text { difference }\end{array}$ \\
\hline
\end{tabular}




\begin{tabular}{|c|c|c|c|c|c|}
\hline & $\begin{array}{c}\text { (North } \\
\text { Caucasia } \\
\text { n Federal } \\
\text { District) }\end{array}$ & & & & $\begin{array}{c}\text { is } \\
\text { insignifica } \\
\text { nt }\end{array}$ \\
\hline 5 & $\begin{array}{l}\text { Bashkort } \\
\text { ostan } \\
\text { Republic } \\
\text { (Volga } \\
\text { Federal } \\
\text { District) }\end{array}$ & 1054 & 0.23 & $23.1 \%$ & $\begin{array}{c}\text { The } \\
\text { difference } \\
\text { is } \\
\text { significant. } \\
\text { but } \\
\text { acceptable }\end{array}$ \\
\hline 6 & $\begin{array}{c}\text { Khanty- } \\
\text { Mansi } \\
\text { Autonom } \\
\text { ous } \\
\text { Region } \\
\text { (Ural } \\
\text { Federal } \\
\text { District) }\end{array}$ & 441 & 0.08 & $8.1 \%$ & $\begin{array}{c}\text { The } \\
\text { difference } \\
\text { is } \\
\text { insignifica } \\
\text { nt }\end{array}$ \\
\hline 7 & $\begin{array}{c}\text { Novosibir } \\
\text { sk Region } \\
\text { (Siberian } \\
\text { Federal } \\
\text { District) }\end{array}$ & 356 & 0.07 & $6.9 \%$ & $\begin{array}{c}\text { The } \\
\text { difference } \\
\text { is } \\
\text { insignifica } \\
\text { nt }\end{array}$ \\
\hline 8 & $\begin{array}{c}\text { Republic } \\
\text { of Sakha } \\
\text { (Yakutia) } \\
\text { (Far } \\
\text { Eastern } \\
\text { Federal } \\
\text { District) }\end{array}$ & 2670 & 0.43 & $42.6 \%$ & $\begin{array}{l}\text { The } \\
\text { difference } \\
\text { is not valid }\end{array}$ \\
\hline
\end{tabular}

An unacceptable difference in repair standards is also observed in two regions - Republic of Sakha (Yakutia) and Belgorod Region.

In this case, we should pay attention to the fact that the normative acts with the values of the standards were approved back in 2009 and 2012. Thus, the mechanism of applying the index-deflator of investments in fixed assets has shown its insolvency. For a period of more than 5 years it does not allow increasing the value of the standard to the level of real cash costs. Consequently, it is determined the need to review and update the standards values no later than 5 years.

Calculations of the magnitude of the variance and the coefficient of variation in between regional and federal values for road maintenance are presented in Table 5.

Table 5. Calculation of variance and coefficient of variation. Maintenance ( $\mathrm{i}=1$ ).

\begin{tabular}{|c|c|c|c|c|c|}
\hline \multirow{2}{*}{ No. } & $\begin{array}{c}\text { Subjects of } \\
\text { the Russian } \\
\text { Federation }\end{array}$ & $\begin{array}{c}\text { Varia } \\
\text { nce }\end{array}$ & \multicolumn{2}{|c|}{$\begin{array}{c}\text { Coefficient of } \\
\text { variation }\end{array}$} & $\begin{array}{c}\text { Interpr } \\
\text { etation } \\
\text { of CV } \\
\text { by FL } \\
\text { No.44 }\end{array}$ \\
\cline { 3 - 5 } $\mathbf{1}$ & $\begin{array}{c}\text { Belgorod } \\
\text { Region } \\
\text { (Central } \\
\text { Federal } \\
\text { District) }\end{array}$ & 391 & 0.74 & $73.5 \%$ & $\begin{array}{c}\text { The } \\
\text { differen } \\
\text { ce is } \\
\text { not } \\
\text { valid }\end{array}$ \\
\hline
\end{tabular}

\begin{tabular}{|c|c|c|c|c|c|}
\hline 2 & $\begin{array}{c}\text { Komi } \\
\text { Republic } \\
\text { (North } \\
\text { Western } \\
\text { Federal } \\
\text { District) } \\
\end{array}$ & 1045 & 5.74 & $573.6 \%$ & $\begin{array}{l}\text { The } \\
\text { differen } \\
\text { ce is } \\
\text { not } \\
\text { valid }\end{array}$ \\
\hline 3 & $\begin{array}{c}\text { Rostov } \\
\text { Region } \\
\text { (Southern } \\
\text { Federal } \\
\text { District) } \\
\end{array}$ & 24 & 0.03 & $3.3 \%$ & $\begin{array}{l}\text { The } \\
\text { differen } \\
\text { ce is } \\
\text { insignif } \\
\text { icant }\end{array}$ \\
\hline 4 & $\begin{array}{c}\text { Chechen } \\
\text { Republic } \\
\text { (North } \\
\text { Caucasian } \\
\text { Federal } \\
\text { District) } \\
\end{array}$ & 50 & 0.08 & $7.7 \%$ & $\begin{array}{l}\text { The } \\
\text { differen } \\
\text { ce is } \\
\text { insignif } \\
\text { icant }\end{array}$ \\
\hline 5 & $\begin{array}{c}\text { Bashkortos } \\
\text { tan } \\
\text { Republic } \\
\text { (Volga } \\
\text { Federal } \\
\text { District) }\end{array}$ & 537 & 1.46 & $146.1 \%$ & $\begin{array}{l}\text { The } \\
\text { differen } \\
\text { ce is } \\
\text { not } \\
\text { valid }\end{array}$ \\
\hline 6 & $\begin{array}{c}\text { Khanty- } \\
\text { Mansi } \\
\text { Autonomo } \\
\text { us Region } \\
\text { (Ural } \\
\text { Federal } \\
\text { District) }\end{array}$ & 27 & 0.03 & $3.0 \%$ & $\begin{array}{l}\text { The } \\
\text { differen } \\
\text { ce is } \\
\text { insignif } \\
\text { icant }\end{array}$ \\
\hline 7 & $\begin{array}{c}\text { Novosibirs } \\
\text { k Region } \\
\text { (Siberian } \\
\text { Federal } \\
\text { District) } \\
\end{array}$ & 18 & 0.02 & $1.9 \%$ & $\begin{array}{l}\text { The } \\
\text { differen } \\
\text { ce is } \\
\text { insignif } \\
\text { icant }\end{array}$ \\
\hline 8 & $\begin{array}{c}\text { Republic } \\
\text { of Sakha } \\
\text { (Yakutia) } \\
\text { (Far } \\
\text { Eastern } \\
\text { Federal } \\
\text { District) }\end{array}$ & 905 & 1.72 & $171.8 \%$ & $\begin{array}{l}\text { The } \\
\text { differen } \\
\text { ce is } \\
\text { not } \\
\text { valid }\end{array}$ \\
\hline
\end{tabular}

In this case, the northern regions of the Komi Republic and Republic of Sakha (Yakutia) were determined for the standards for roads maintenance with significant heterogeneity and an unacceptable difference. This can be explained by the influence of the natural and climatic factor on increasing financial costs, which led to a deliberate understatement of standards in the regions due to the limited budget funds.

\section{Conclusion}

The results of the analysis of the data obtained in the course of the preliminary survey study of Russian rulemaking practice showed that such regions of the Federation as Chechen Republic, Khanty-Mansi Autonomous Region, Novosibirsk Region, which are distinguished by their economic potential, political 
authority and leading position in their macro-territories, have shown the best results in tightness to federal standards. The value of the coefficient of variation was less than $10 \%$ and is stable for all types of work.

Insignificant deviation indicates the establishment of regional standards practically at the federal level. The results obtained are important for the regional executive power and can serve as an additional justification for the determination and establishment of target tariff policy. That is, when developing regional norms and rules, calculate and approve such sizes of basic standards that could be close to those established for federal highways.

\section{References}

1. V.N. Bogomolov, Report on the results of the control event "Checking the use of budgetary allocations aimed at the maintenance of public highways of federal, regional and intermunicipal importance in 2018 and the past period of 2019" (with the control and accounting bodies of the constituent entities of the Russian Federation), Accounts Chamber of the Russian Federation, 2 (2020)

2. P.V. Gulyaev, Gornyi Zhurnal 12, 23-26 (2018)

3. V.V. Nikiforova, E.R. Romanova, E.E. Grigorieva, Gornyi Zhurnal 3, 41-46 (2018)

4. E.E. Grigoryeva, IOP Conference Series: Earth and Environmental Science 302(1), 012138 (2019)

5. T.P. Egorova, A.M. Delakhova, Proceedings of the International Conference "Aviamechanical engineering and transport" (AVENT 2018) Series: Advances in Engineering Research 158, 123-129 (2018)

6. V.N. Leksin, B.N. Porfiryev, Economy of Region 3, 641-657 (2017)

7. V.N. Borisov, O.V. Pochukaeva, Studies on Russian Economic Development 27(2), 159-165 (2016)

8. T.P. Egorova, A.M. Delakhova, Smart Innovation, Systems and Technologies 138, 272-282 (2020)

9. T.P. Egorova, A.M. Delakhova, IOP Conference Series: Materials Science and Engineering 632(1), 012029 (2019)

10. D.V. Filippov, IOP Conference Series:
Materials Science and Engineering 753(5), 052048 (2020)

11. S.V. Fedotov, T.F. Matyushenko, Roads and bridges 2(18), 11-20 (2007)

12. V.V. Gasilov, M.A. Preobrazhensky, S.S. Zamchalova, M.A. Shibaeva, Science and technology in the road industry 2 , 10-12 (2002)

13. A.S. Eremeeva, News of higher educational institutions. Series: Economics, Finance and production management 2(12), 3-9 (2012)

14. E.A. Latkina, T.F. Matyushenko, Roads and bridges 2(38), 1 (2017)

15. I.A. Kurbatov, Bulletin of the Moscow automobile and road state technical University (MADI) 3(22), 60-63 (2010)

16. V.K. Apelin, Roads and bridges 18(2), 20-29 (2007) 